\title{
An Empirical overview of Microenterprises and Microfinance Development in Nepal
}

\author{
Prof. Dr. Puspa Raj Sharma
}

\begin{abstract}
This paper aims an overview of microfinance and microenterprises development and analyze the related various dimensions of the micro-enterprises. It focuses on registration status, causes of registration and non-registration, employment status and participation of women in the microenterprises, problems related to microenterprises, training need assessment and their effectiveness, microinsurance and their status.
\end{abstract}

Key words: Microfinance, microenterprises, training.

\section{Introduction}

There is robust evidence that countries with better -developed financial system experience faster reductions in income inequality and and faster rates of poverty alleviation (yunus, 2003). Whereas the development of an efficient financial system is associated with pro-poor growth, immediate benefits derived from credit, savings and payment services accrue only those who have direct access to financial system. These benefits include the opportunity to accumulate productivity-enhancing capital that can increase income, the means to safely put money away in savings account for use in an emergency, the ability to efficiently access transfer payments from relatives, working away from home. In Kenya (CECI, 1999) for example poor people savings and loans to invest in assets business activities (inventories, salaries), save for the future (educational and medical costs), manage household cash-flow needs (rent, food), invest in assets (land housing, appliances) and cope with crisis or life events (illness, marriage and funerals).

\subsection{Literature Review : review of related studies}

Rabinson(1996) concluded that the socio-economic impact on the households was less visible due to the limited time-period of the study. In both countries, the transaction costs of administering the grants and the loans were in the range of 10-20 percent of the value of the capital provided. However survey show an increase in recipients' income in both countries (Nepal and Uganda).

CECI (1999) showed improvement in women's confidence in raising their voices in the public and carrying social reform activities. Proportion of women undertaking income generating activities such as poultry raising, petty shops etc. also increase significantly. The women also have greater control over house.

Agrwal and Chatterji (2000) found that the major issues in the rural financial sector include limited outreach; high transaction costs; inadequate legal and regulatory framework and national micro-finance policy.

Ahmed (2002) observed higher productivity in agriculture after the intervention of the program in agriculture. 
World Bank (2002) observed that CBOs faced certain problems such as account keeping, distribution of profit, capability of development negotiations and advocacy. Training was not tailored to the need of the target of the group.The MFIs program was found to be successful in raising confidence among the women and enhancing the status of women in the society.

Asian Development Bank (2002) explained a number of positive impacts on poor. Beneficiaries acquired social and personal benefits from belonging to self-help groups and co-operatives.

Sharma (2003) found that the outreach of micro finance program is estimated to be 44.3 percent using the poverty figure of 38 percent. He concluded that the numbers of MFIs in Nepal are not adequate to cater to the financial needs of the poor households.

Shrestha (2003) realized over regulated and concluded that micro-finance activities in Nepal are governed by at least ten acts of Parliament.

Littlefield et.al (2004) found that 68 percent of its members were making decisions on buying and selling property, sending their daughters to school, negotiating their children's marriages, and planning their family. Husbands traditionally made these decisions.

Shrestha (2005) found terai farmers performed better than hill farmers. Farm income increased by 19.5 percent, whereas off-farm income increased by 68 percent, concluded higher change in non-farm activities after MFIs involvement.

Agrawal (2005) pointed out the major problem with GBB are: low expansion, especially to hill area, limited capital, low literacy and lack of services to the poorest of the poor. He concluded that female functional literacy programs, rural infrastructure, marketing facilities and other services (such as veterinary services, and agricultural extension) are pre-conditioned for the sustainability and effective expansion of the activities.

Shrestha (2005) observed that the program has made sufficient contribution towards increasing household assets such as moderate housing, improved livestock, bullock carts. Similarly, savings share and insurance funds have been increased.

Center of Micro Finance (CMF, 2005) concluded that the micro-finance and other services provided by the SACCOSs had generated impact not only on the livelihood of members at individual and households levels, but also on the community. The impact was in terms of decrease in interest rates, principally charged by moneylenders, within the community; availability of better financial services in the hills; establishment and expansion of markets in the community; and build-up of social capital..

CMF (2008) found women outside of MFIs program are found to be equally or more poor than women associated with the program. This indicates that women development program have not reached to many needy women. This exclusion issue indicates the inadequacy of coverage. These women involved in the program have more mobility, more confident and self-esteem and have increased decision making power than women outside of the programs. However, women development programs are not able to bring gender role transformation. There is no significant change in gender role. 


\section{Data and Methods}

The study is mainly focused and overview of micro-enterprises and MFIs. For this, basically a survey was conducted to MFIs client who are running microenterprises development. In addition to this descriptive cross sectional analytical research design was adopted. As a frame of reference, various scattered research works were used which helped to analyze and interpret the qualitative and quantitative data. For the purpose of primary data collection a structured questionnaire survey was done. Besides this, focused group discussion with credit group of MFIs and in-depth interviews with chief of MFIs were conducted. In the process of the study observation and field visits were done in various MFIs of Nepal, Bangladesh's MFIs.

The sampling process has been used on a phase-wise basis to meet the objectives of the study. First of all, the MFIs, were selected which have, adopted Grameen Model and running at least four years of operation from private and public sectors. After that four largest MFIs were selected from the total number of nine MFIs in Nepal. Two largest from privately initiated (PI) institutions i.e. NUB, SBB and two largest MFIs from government initiated (GI) institutions i.e. WGBB and CGBB were taken.

\section{Discussion and Analysis}

The study tried to explore various related aspects of the borrower's business and their attitude. In this process registration, cause of registration, cause of non-registration, employment status and women participation was explored.

\section{1 Clients Business Registration and Employment Status}

Registration status of the client's business is an important aspect for future expansion and growth and formalization of activities. For the institutional financing purpose also it is necessary to register.

Table 1: Business registration status

\begin{tabular}{|l|c|c|}
\hline \multicolumn{1}{|c|}{ Registrations status } & No.of cases & Percentage \\
\hline Yes & 33 & 11 \\
\hline No & 201 & 67 \\
\hline Don't know & 66 & 22 \\
\hline Total & 300 & 100 \\
\hline
\end{tabular}

As presented in the table, MFI's clients did not appear to be aware about the registration of their business activities. Only 11 percent business activities were in registered. Majority of businesses (57 percent) were not registered.

Registered businesses were asked where they registered. The places of registrations were VDCs (64 percent) Chamber of Commerce and Industry (18 percent), District Cottage Industry Office (6 percent) and the Municipality (12 percent). It showed that a very few businesses were interested in registration. 
Table 2: Registrations status of the clients business activities

\begin{tabular}{|l|c|c|}
\hline \multicolumn{1}{|c|}{ Place of registrations } & No. of cases & Percentage \\
\hline VDC & 21 & 64 \\
\hline Chamber & 6 & 18 \\
\hline DCI office & 2 & 6 \\
\hline Municipality & 4 & 12 \\
\hline
\end{tabular}

Table: 3 Causes of Registrations and Non-Registrations

\begin{tabular}{|l|c|l|c|}
\hline \multicolumn{1}{|c|}{ Cause of not-registrations } & Percent & \multicolumn{1}{|c|}{ Cause of registrations } & Percent \\
\hline Tax problem & 14.7 & Legal provisions & 42 \\
\hline Difficult legal provisions & 17.7 & Business publicity & 18 \\
\hline Annual renewal & 23.0 & Business growth & 12 \\
\hline Misbehaviors govt. staff & 10.6 & Access of loan facility & 18 \\
\hline Not responded & 34.0 & Not responded & 10 \\
\hline Total & 100 & Total & 100 \\
\hline
\end{tabular}

The main causes for the action were also assessed. The causes of registration were business growth and publicity (18 percent), loan facility (18 percent) and minimum legal requirement (42 percent). Similarly the causes of non-registrations were tax problem (14.7 percent), difficult legal provision (17.7 percent), annual renewal provision (23 percent), and behavior of government staff (10.6 percent ) and 34 percent did not responded.

\subsubsection{Employment Status}

Table : 4 Person Employed and Status of Women Employee

\begin{tabular}{|l|c|c|l|c|c|}
\hline \multicolumn{3}{|c|}{ Employment status } & \multicolumn{3}{c|}{ Percentage of women employee } \\
\hline Particulars & No. of cases & Percent & Particulars & No. of cases & Percent \\
\hline Less than 3 & 283 & 94.3 & $\begin{array}{l}\text { Less than 20 } \\
\text { percent }\end{array}$ & 60 & 20 \\
\hline 3-5 persons & 14 & 4.7 & $\begin{array}{l}20-50 \\
\text { percent }\end{array}$ & 168 & 56 \\
\hline $\begin{array}{l}\text { Above 5 } \\
\text { persons }\end{array}$ & 3 & 1.0 & $\begin{array}{l}50-80 \\
\text { percent }\end{array}$ & 72 & 24 \\
\hline Total & 300 & 100 & Total & 300 & 100 \\
\hline
\end{tabular}

Employment status of the business shows their size of operation and composition of employee shows the position of the women within the enterprises. Women have been shown to spend more of their incomes on their households; therefore, when women are helped to increase their incomes, the welfare of the whole family is improved. The special unit on Micro-finance of the CMF (2004) explains, "women's success benefits more than 
one person. Several institutions confirmed the well-documented fact that women are more likely than men to spend their profits on household are and family needs. Assisting women therefore generates a multiplier effect that enlarges the impact of the institutions activities."

Majority of the business activities was based on self-employed approach having less than three persons in each unit. Out of three mostly household member husband, son, daughter and other family members were involved. In these activities mostly women's involvement was found. Business operation style showed that they were operating especially for their livelihood rather than as a professional businessman.

\subsection{Opinion about MFIs Contribution}

Women's increased income benefits their children, particularly in education, diet, health care, and clothing. Opinion about MFI contribution on education and health and the response in included in the table.

Table: 5 Opinions about MFIs Contributions

\begin{tabular}{|l|c|c|l|l|l|l|c|c|}
\hline \multicolumn{2}{|c|}{$\begin{array}{c}\text { Contributions to educate } \\
\text { children }\end{array}$} & \multicolumn{3}{|c|}{ Increase in education level after } & \multicolumn{3}{c|}{ Changes in personal health and } \\
caring
\end{tabular}

In order to understand the impact, most of the respondents have expressed positive attitude towards MFI regarding support to educate children, their level of education, and support to maintain good health of their children

Table: 6 Satisfaction about the Savings Product and Rate of Interest Rate

\begin{tabular}{|l|c|c|}
\hline \multicolumn{1}{|c|}{ Opinion } & No of cases & Percent \\
\hline Completely satisfied & 3 & 1 \\
\hline Fair /ok & 210 & 70 \\
\hline Dissatisfied & 69 & 23 \\
\hline Don't know & 18 & 6 \\
\hline Total & 300 & 100 \\
\hline
\end{tabular}

The respondents did not appear to be fully happy about the prevailing interest rate on savings and various savings schemes. MFIs have charged different rates of interest on the loan extended under different programs. The rate varies from flat interest rate of 10 percent for each weekly installment or flat interest rate of 20 percent for each 
fortnightly installment to a simple interest rate of 25 percent per year.

They observed there was a wide gap between the lending rate and deposit rate of the MFIs. They have paid about 20-25 percent interest rate on their loans but they receive only 6 percent on their savings. Savings schemes were also very limited which may not match with the need of the clients.

Table :7 The Role of Insurance in Minimizing the Level of Risk

\begin{tabular}{|l|c|c|}
\hline \multicolumn{1}{|c|}{ Response } & No of cases & Percent \\
\hline Yes & 150 & 50 \\
\hline No & 51 & 17 \\
\hline Don't know & 99 & 33 \\
\hline Total & 300 & 100 \\
\hline
\end{tabular}

Majority felt the importance of insurance. Fifty- percent respondent agreed with the role of in a minimizing the level of risk in the business activities. They expressed that only a limited ranges of insurance services were available for them. Those services terms and conditions were not clarified adequately by the MFIs.

Table: 8 Improvement Status in Food Habit after MFIs

\begin{tabular}{|l|c|c|}
\hline \multicolumn{1}{|c|}{ Any improvement in food habit after MFI } & No. of cases & Percent \\
\hline Completely agree & 19 & 6.3 \\
\hline Agree & 228 & 76 \\
\hline Disagree & 53 & 17.7 \\
\hline Total & 300 & 100 \\
\hline
\end{tabular}

To observe the program impact, respondents were asked about the whether it helped to change in food habits or not. As presented in the table, the majority (76 percent) agreed with some improvements in the food habits after the program involvement.

\subsection{Problem in Operating Micro-Enterprises/Business Activities}

Most of the institutions and programs may have suffered from institutional inefficiencies and poor financial performance. In the rural context, lack of adequate access to financial services hinders the utilization of economic opportunities and contributes to income inequalities. Generally, borrowers themselves have to identify business plan that may be initiated with small investment. In rural areas opportunities of small credit are limited with increasing activities local opportunities soon become saturated. A large number of participants in the focus group discussion opined that many poor and vulnerable household were not motivated to the groups because of the difficulty in identifying viable enterprises and marketing their products. Clients faced difficulty in selling products due to political and economic instability in the country 
(Sharma, 2007). In this backdrop the business problems are presented as below.

Table : 9 Problem in Micro-Enterprises/ Business Activities

\begin{tabular}{|l|c|}
\hline \multicolumn{1}{|c|}{ Problems } & Percent \\
\hline Economic instability (reasonable price, Bandh, Chakkajam) & 66 \\
\hline Marketing (transportation, warehouse, lack of demand) & 40 \\
\hline Productions (shortage material, load shading, other accessories) & 20 \\
\hline Human resource (lack of skill, lack of trained manpower) & 16 \\
\hline $\begin{array}{l}\text { Financial /accounting (lack of systematic accounting and financial } \\
\text { knowledge, financing problems) }\end{array}$ & 21 \\
\hline Other problems (updated technology) & 10 \\
\hline
\end{tabular}

As presented in the table, currently the clients' economic activities have suffered from economic instability (66 percent) followed by marketing related problems (40 percent). Similarly, financial/ accounting, production, human resource, and other various problems were ranked third, fourth, fifth and sixth respectively.

\subsection{Training Need Assessment}

Capacity building is an essential part for the success and growth of MFIs. Without the growth and economic development, the sustainability of the MFIs may not be possible. In this context, clients' capacity building and efficiency through training is essential. The training needs of the clients revealed following needs:

Table: 10 Training Need Assessment

\begin{tabular}{|l|c|c|}
\hline \multicolumn{1}{|c|}{ Area of training need } & No. of cases & Percent \\
\hline Skill oriented (cutting, netting, beauticians) & 159 & 53 \\
\hline Market oriented (salesmanship/basic marketing) & 57 & 19 \\
\hline Production (Agriculture/livestock/poultry) & 60 & 20 \\
\hline $\begin{array}{l}\text { Saving and credit mobilizations (accounting and basic } \\
\text { finance) }\end{array}$ & 18 & 6 \\
\hline Others (not included in above) & 6 & 2 \\
\hline
\end{tabular}

Majority (53 percent) emphasized on the need for skill oriented training for their growth and development. Other areas of training needs were: market oriented, production and saving and credit mobilization, they emphasized. 


\section{Conclusions and Recommendations}

The mix types of result were observed in the past also from the various empirical studies outside the nation about the micro-finance services. Entrepreneurship development has not been a motivating factor for making the members realize the importance of being in the group. A large proportion of respondents did not receive any entrepreneurship development training, while the other who received training also did not find the training to be useful in carrying out micro- enterprises.

No single intervention can defeat poverty (WB, 2002). Poor people need employment, schooling and health care. Some of the poorest require immediate income transfers or relief to survive. Access to financial services serves a fundamental basis on which many of the other essential interventions depend (Yunus, 2003). Moreover, improvement in health care, nutritional advice and education can be sustained only when households have increased earnings and greater control over financial resources (Robinson, 1996). Financial services thus reduce poverty and its effects in multiple concrete ways. And the beauty of microfinance is that as program approach financial sustainability, they can reach far beyond the limits of scarce donor resources (Sharma, 2004).

A number of positive impacts were seen in the study such as : reducing illiteracy, women's participation in decision making, changes in occupational structure, health awareness, food sufficiency, safe drinking water, use modern latrine, nutritious food consumption's, easy financial sources for investment with low rate of interest, improvement in housing construction and repair of roof and slight improvement in medium value of assets. It shows the MFIs are not only confined in credit services but also in social services. However a number of shortcomings and weaknesses were also observed as limited outreach, low/no access in hills and mountains, no services for the poorest of the poor, low status of registrations of micro-enterprises, low capacity building of the clients, lack of skill oriented and other functional training. Conducting business activities with small loan by producing / selling liquor at their own home negatively influenced the family member and community also ultimately. Starting same kind micro activity at the same place create problem of lack of market and customers. Limited schemes of savings, lending and insurance are the limitation in clients' choices. Traditional type of services of the MFIs may not match the growing and diversified need of the clients. The challenges are there for MFIs to cope with the changing need of the clients

\section{BIBLOGRAPHY}

Agrawal, G. R., \& Chatterji, S. (2000). A review of the financial sector in Nepal. Kathmandu: Department for International Development (DFID).

Agrawal, G. R. (2003). Critical issues and poverty reduction through rural credit in Nepal. Agriculture Credit, 30. 
Agrawal, G. R. (2005). Rural entrepreneurship and agricultural development bank. Agriculture Credit, 38.

Ahmed, M. (2002). Key to achieving sustainability. Dhaka : ASA's Publication.

Asian Development Bank. (2002). Finance for the poor. Manila:ADB/M

CECI. (1999). Women's empowerment through micro-finance: the case of micro credit project for women. Occasional Paper, 2.

Center for Micro-Finance. (2008). A research report on relative poverty assessment study of nirdhan utthan bank clients in nepal. Kathmandu: CMF.

Center For Micro-finance. (2003). Directory of MFIs in Nepal. Kathmandu: CMF

Center for Micro-Finance. (2005). Impact assessment of SACCOSS in Nepalese hill districts- findings of an action research. Kathmandu: CMF.

Ledgerwood, J. (1995). Philippines poverty strategy report: access to credit for the poor. Washington DC: World Bank, East Asia Country Department.

Ledgerwood, J. (1997). Critical issues in nepalese micro-finance circumstances iris center. Maryland.

Littlefield, E., Morduch, J., \& Syed, H. (2004). Is micro-finance and effective strategy to reach MDG ? Focus Note 24. Washington DC: CGAP

Morduch, J. (1999).The micro-finance promise. Journal of Economic Literature, XXXVII (4), 1569-1614.

Ostergaard, L. (1992). Gender and development: a practical guide. London: Routledge.

Rhyne, E., \& Maria, O. (1994). A financial system approach to micro-enterprises GEMINI. Working Paper 18, Washington DC.

Robert, G. (1990). The informal financial sector in bangladesh: An appraisal of its role in development. Development and Change 23, 147-68

Robinson, M. S. (1996). Addressing some key questions on finance and poverty. Journal of International Development 8(2),153-61

Schmidt, R. H., \& Claus-Peter, Z. (1996). Prospects, problems and potential of credit granting NGOs. Journal of International Development, 8(2), 241-58.

Schuurman F. J. (Ed.) (1993). Beyond the impasse: New directions in development theory. London: Zed Books.

Sharma, P. R. (2003) micro-finance programs and delinquency management in Nepal . Comment Paper on the Paper presented in a Seminar Organized by SAP-Nepal, Pokhara, Dec.12

Sharma, P. R. (2004). Micro-finance programs and its sustainability in Nepal. Paper presented in a Seminar organised by SAP-Nepal, Pokhara, July 5 
Sharma, P. R. (2004). Micro-finance: A powerful tool for social transformation, its challenges and principles. The Journal of Nepalese Business Studies, 1(1), 69-74.

Sharma, P. R. (2003). Micro-finance programs and its strategy to deliver services on poorest of the poor in Nepal. Paper presented in a Seminar organized by South Asia Partnership Nepal, Pokhara , Dec.31

Shrestha, S. M. (2005). Why interest rate of MFI is high than the other commercial banks?. Micro-finance Bulletin. Kathmandu: RMDC

World Bank. (2002). World development report 2002/2003, attacking poverty. New York: Oxford University Press

Wright, G. A. N. (1999). Examining the impact of micro-finance services increasing income or reducing poverty. Small Enterprise Development, 10(1), 39-47.

Yunus, M. (2002). Grameen Bank II : Designed to open new possibilities? Originally published in grameen dialogue. Dhaka: Grameen Bank

Yunus, M. (2003). Halving poverty by 2015.We can actually make it happen? Mirpur Dhaka: Grameen Bank 